\title{
Research on Hotspots and Trends of Public Service Coordinated Supply*
}

\author{
Yuanfang Liu \\ School of Ethnology and Sociology \\ Inner Mongolia University \\ Hohhot, P.R. China
}

\author{
Xi Guo \\ School of Ethnology and Sociology \\ Inner Mongolia University \\ Hohhot, P.R. China
}

\author{
Dongxu Li \\ School of Public Management \\ Inner Mongolia University \\ Hohhot, P.R. China
}

\begin{abstract}
The 19th National Congress of the Communist Party stated that constructing and improving public service supply system is an inevitable requirement for the party and the government to improve people's livelihood and to strengthen innovative social governance in the new era." This paper analyzes the trends and hotspots of domestic public service coordinated supply through knowledge map supported by Citespace software, which shows that although the research on the coordinated supply of public services in China is emerging, there are certain limitations. There are few studies on public services and true satisfaction of people, the main audience of the service; performance research is in its infancy; the theoretical analysis of coordinated supply hasn't yet been deepened, and the research on the coordinated supply of public services in ethnic areas is relatively scarce. In such circumstances, future research can further explore the development trend of public service coordinated supply mechanism, explore the quantitative analysis method and enrich the research in ethnic areas.
\end{abstract}

Keywords-public service; coordinated supply; knowledge map; hotspot; trend; coordinated supply; public services

\section{INTRODUCTION}

Public service is the cornerstone for ensuring people's basic life, promoting people's development, and maintaining social stability. Its contents include education, medical care, labor and employment, social insurance, social services, population and family planning, housing, disabled people, public culture and sports, etc. General Secretary Xi Jinping emphasized in the report of the 19th National Congress of the Communist Party of China, We must constantly make new progress, so that every kid is well raised and educated, everyone has work to do, everyone has a roof over the head, every sick is treated and the elderly taken care of." The public service coordinated supply is a new supply method

*This research was supported by the China national natural science foundation - Research on evolution game, decision optimization and performance evaluation of cooperative supply of public services" (No. 71864025) and the Enhancing Comprehensive Strength Foundation of Inner Mongolia University (No. 10000-16010109-35). based on the reality of the fragmentation of public service supply. It can directly respond to the complex demand of public services, effectively integrate the decentralized and fragmented supply situation, and effectively improve the supply efficiency of public services; it can also alleviate the crisis of the welfare country, transform government functions, increase market organization profits, shape a good image, improve the status of social organizations, and enhance its institutionalization. The realization of the public services coordinated supply is affected by factors such as interest relations, social capital and coordination capabilities. The realization of the coordinated supply of public services in ethnic areas, will not only help the residents of ethnic areas to enjoy public services fairly, but also contribute to the unity and stability in the ethnic areas, which helps the realization of the unity, mutual assistance and common development of the people of all nationalities in the country.

\section{PROBLEM DESCRIPTION}

The new public service school, represented by Robert B. Denhart, believes that the government should not control, and motivate, but to do service in its administration [1] (Denhardt R B, 2010). As an important means for ruling parties and the public sectors to integrate social resources, enhance people's well-being, and enhance their ability to govern, public service supply has received much attention in recent years. The 19th National Congress of the Communist Party pointed out that "constructing and improving the public service supply system is an inevitable requirement for the party and the government to improve people's livelihood and strengthen the innovative social governance in the new era." The provision of public services has become a good way to solve the contradiction between unbalanced and inadequate development and the people's ever-growing need for a better life." General Secretary Xi Jinping also stressed the need to "improve the public service system, guarantee the basic livelihood of the people, continuously meet the people's growing needs for a better life, and form effective social governance and a good social order, so that the people can 
have a sense of happiness and security, becoming more secure and sustainable."

However, the current public service supply in China has the phenomenon of scattered subjects, complex requirements, multiple procedures, and insufficient and imbalanced results, making coordinated supply an important choice for public service supply. [2] [3] [4] [5] [6] [7] From the perspective of policy, the government encourages the role of the market in the provision of public services to further clarify the powers and responsibilities in the supply of public services. The 43th Five-Year Plan for Promoting the Equalization of Basic Public Services" promulgated by the State Council in 2017 states that the role of the market mechanism should be fully utilized to support the equal participation of all types of entities and provide services to form a synergy for the expansion of supply", which provided guidance with multisubject participation; the Central and Local Common Financial Affairs and Expenditure Responsibility Reform Plan for Basic Public Service Fields" issued in 2018 further emphasized the government's financial input and responsibility division, which reflects the powers and responsibilities in the government service synergy are further clarified in the new era. At the same time, the rapid development of modern information science and technology such as cloud computing, big data, artificial intelligence, blockchain, etc., provides technical support and convenient conditions with multi-cooperation, dynamic monitoring and public participation of coordinated supply.

Some scholars believe that the public service coordinated supply is a process in which the government, market organizations and social organizations take people's needs as orientation through full communication and coordination to achieve the advantages complement and the information and resources are shared. [8] In this process, all the elements are coordinated and cooperated with each other under the guidance of certain rules. The coordinated supply of public services in the new era is considered by scholars as a new model of public services, which can promote the supply efficiency of public services, improve the quality of public services, enhance the satisfaction of public services and increase public welfare.

\section{RESEARCH STATUS AND DEVELOPMENT TRENDS AT HOME AND ABROAD}

The "Public service coordinated supply" is closely related to China's social governance and national development strategy, and it has attracted increasing attention from the academic community and is in the ascendant trend. As a research tool of big data social science, the knowledge map uses the literature information of the journal database as the medium to realize the research content in the form of images by integrating the important content of the literature review research such as time, key content and cited information. The dynamic tracking and comprehensive reflection help researchers to explore the method value and innovation significance in scientific research through the map. The CiteSpace quantitative literature statistical tool is used as the carrier to draw the knowledge map of public service coordinated supply research. Through multi-dimensional description, it forms an objective and comprehensive review of the subject trends, and focuses on the hot issues and research trends to look forward to the public service coordinated supply research expansion space and subject development prospects in the new era.

\section{A. Analysis of Highly Cited Literature}

The research uses the CNKI as the source database, using the quantitative literature measurement visualization method and Citespace software, and the 63 core journals and CSSCI papers with the theme of public service" and -oordinated supply" are retrieved. The sample finds the top ten representative documents, sorts out the top ten literature titles, authors, citations, and publication years according to the rankings (see "Table I"), and draws the knowledge map evolution map (see "Fig. 1").

According to the top ten literatures which show the highcited documents from 2009 to 2016, we can find: First, regarding the Chinese government's provision of public service coordinated supply, the earliest research began with the supply of rural public services. There is a serious problem of fragmentation". As a major direction for public service supply, research on the coordinated supply of rural public services is also the focus of scholars. Wang Jinjun's "Rural Public Service Provision: A Way to Surpass the "Fragmentation" of coordinated Supply - Chengdu's Public Service Coordination Reform and Implications for Rural Public Service Supply Model" and Zhang Xianming and Tian Yuxi's "Integration Fragmentation: the principle of coordinated supply of public services. Taking Chengdu as an example, Wang Jinjun believes that in the rural public service, the traditional single supply model faces problems that are difficult to solve by itself, like the bureaucratic dilemma of the government-led supply model, the resource dilemma of the autonomous supply model, and the supervision of the entrusted supply model dilemma. Moreover, these traditional supply models are too fragmented in the provision of public services, and they are unable to provide an overall coordinated mechanism for rural public services. Therefore, proposals for coordinated supply of rural public services in Chengdu are given. Wang Jiegui et al. proposed a diversified coordinated supply model for rural public services based on farmers' satisfaction. The fragmentation" of public service supply is mainly due to the decentralization of supply entities, government departments, supply procedures, and non-equalization of supply, the waste of resources and time leads to the government's high cost and low efficiency". The institutional dilemma is difficult to provide citizens with seamless services.

Secondly, the research perspective on the coordinated supply of public services is mainly based on synergy theory, governance theory, holistic theory and symbiosis theory represented by Ma Yuhua et al.'s Study on the Cooperative Supply of Public Sports Services in China under the Background of Government Transformation - Based on the Perspective of Overall Government Theory, Guo Yangqiang and Du Jinsui's Research on the Cooperative Supply of Public Services from the Perspective of the Whole Government, Zhu Hanping and Jia Haiwei's Government 
and Social Organizations Collaboration to Provide Rural Aged Care Services: An Analysis Based on the Perspective of Synergetic Governance Theory and Zhao Manli's Public Service coordinated Supply Research: Analytical Framework Based on Symbiosis Theory.

Finally, in the coordinated research of public services, focusing on sports, culture and public services for the elderly, there are few studies on medical and educational public services. For example, Shen Keyin's Local Practice and Promotion Strategy of coordinated Governance between Government and Sports Social Organizations - Taking Changzhou Municipal Government Purchasing Public Sports Services as an Example, Zheng Li's Research on the coordinated Governance Path of Rural Public Sports Service Supply Side Reform, Ma Yuhua et al Research on the Cooperative Supply of Public Sports Services in China under the Background of Government Transformation - Based on the Perspective of Overall Government Theory, Ma Xuesong's Responding to Demand and Effective Supply: Institutional Analysis of the Construction of Basic Public Cultural Service System, and Zhu Hanping, Jia Haiwei's Government and the promotion idea of social organizations to provide rural old-age services in an effort - based on the perspective of coordinated governance theory.

TABLE I. TOP10 Highly Cited Literature in Public Service COORDINATED SUPPLY

\begin{tabular}{|c|c|c|c|c|}
\hline Ranking & Title & Author & Cited & Year \\
\hline 1 & $\begin{array}{l}\text { Rural Public } r \text { Service } \\
\text { Provision: A Way to } \\
\text { Surpass } \\
\text { "Fragmentation" the } \\
\text { Synergistic Supply - The } \\
\text { Coordinated Reform of } \\
\text { Chengdu Public Service } \\
\text { and Its Enlightenment to } \\
\text { the Rural Public Service } \\
\text { Supply Model }\end{array}$ & $\begin{array}{l}\text { Wang } \\
\text { Jinjun }\end{array}$ & 37 & $\begin{array}{l}20 \\
11\end{array}$ \\
\hline 2 & $\begin{array}{l}\text { Research on Diversified } \\
\text { Collaborative } \\
\text { Mode of Rupply } \\
\text { Service Oriented bublic } \\
\text { Farmers' Satisfaction }\end{array}$ & $\begin{array}{l}\text { Wang } \\
\text { Jiegui, Yan } \\
\text { Zhijun, } \\
\text { Zhang } \\
\text { Junhua }\end{array}$ & 27 & $\begin{array}{l}20 \\
12\end{array}$ \\
\hline 3 & $\begin{array}{l}\text { Equalization of Urban and } \\
\text { Rural Basic Public } \\
\text { Services in the Process of } \\
\text { Urbanization - Analysis } \\
\text { Framework Based on } \\
\text { Supply and Demand } \\
\text { Perspective and Its Path } \\
\text { Selection }\end{array}$ & $\begin{array}{l}\text { Yu Wei, } \\
\text { Yu Jia. }\end{array}$ & 25 & $\begin{array}{l}20 \\
14\end{array}$ \\
\hline 4 & $\begin{array}{l}\text { From "State Unilateral } \\
\text { Supply" to "Social Co- } \\
\text { governance" }- \text { Research } \\
\text { on the Transformation of } \\
\text { County Rural Public } \\
\text { Service Model in the } \\
\text { Context of Synergetic } \\
\text { Learning }\end{array}$ & $\begin{array}{l}\text { Fang Kun; } \\
\text { Xiao Wei }\end{array}$ & 25 & $\begin{array}{l}20 \\
09\end{array}$ \\
\hline 5 & $\begin{array}{l}\text { Responding to Demand } \\
\text { and Effective Supply: An } \\
\text { Institutional Analysis of } \\
\text { the Construction of Basic } \\
\text { Public Cultural Service } \\
\text { System }\end{array}$ & $\begin{array}{l}\text { Ma } \\
\text { Xuesong }\end{array}$ & 23 & $\begin{array}{l}20 \\
13\end{array}$ \\
\hline
\end{tabular}

\begin{tabular}{|c|c|c|c|c|}
\hline Ranking & Title & Author & Cited & Year \\
\hline 6 & $\begin{array}{llr}\text { Research } & \text { on } & \text { the } \\
\text { Cooperative } & \text { Governance } \\
\text { Path of Rural Public } & \text { Sports } \\
\text { Service } & \text { Supply } & \text { Side } \\
\text { Reform } & & \end{array}$ & Zheng Li & 19 & $\begin{array}{l}20 \\
16\end{array}$ \\
\hline 7 & $\begin{array}{l}\text { Local Practice and } \\
\text { Promotion Strategy of } \\
\text { Collaborative Governance } \\
\text { between Government and } \\
\text { Sports Social Organization } \\
- \text { Taking Changzhou } \\
\text { Municipal Government } \\
\text { Purchasing Public Sports } \\
\text { Service as an Example }\end{array}$ & Shen Keyin & 16 & $\begin{array}{l}20 \\
17\end{array}$ \\
\hline 8 & $\begin{array}{l}\text { Structure, Resources, } \\
\text { Subject: Coordination of } \\
\text { Basic Public Services }\end{array}$ & $\begin{array}{l}\text { Ma } \\
\text { Xuesong }\end{array}$ & 16 & $\begin{array}{l}20 \\
16\end{array}$ \\
\hline 9 & $\begin{array}{l}\text { Reconstruction of China's } \\
\text { Rural Public Goods Supply } \\
\text { System from the } \\
\text { Perspective of Synergetics }\end{array}$ & Li Wei & 16 & $\begin{array}{l}20 \\
09\end{array}$ \\
\hline 10 & $\begin{array}{l}\text { Integrated Fragmentation: } \\
\text { The Synergistic Supply of } \\
\text { Public Services }\end{array}$ & $\begin{array}{l}\text { Zhang } \\
\text { Xianming } \\
\text { Tian } \\
\text { Yuzhen }\end{array}$ & 15 & $\begin{array}{l}20 \\
15\end{array}$ \\
\hline 11 & $\begin{array}{l}\text { Research on collaborative } \\
\text { supply of public services: } \\
\text { an analytical framework } \\
\text { based on symbiosis theory }\end{array}$ & Zhao Manli & 15 & $\begin{array}{l}20 \\
12\end{array}$ \\
\hline 12 & $\begin{array}{l}\text { Research on the } \\
\text { Cooperative Supply of } \\
\text { Public Sports Service in } \\
\text { China under the } \\
\text { Background } \\
\text { Government } \\
\text { Transformation-Based on } \\
\text { the Perspective of Holistic } \\
\text { Government Theory }\end{array}$ & $\begin{array}{l}\text { Ma Yuhua, } \\
\text { Wang Li, } \\
\text { Lin Li }\end{array}$ & 14 & $\begin{array}{l}20 \\
14\end{array}$ \\
\hline 13 & $\begin{array}{l}\text { The Advancement of } \\
\text { Government and Social } \\
\text { Organizations in Providing } \\
\text { Rural Elderly Care } \\
\text { Services - Based on the } \\
\text { Analysis of Collaborative } \\
\text { Governance Theory }\end{array}$ & $\begin{array}{l}\text { Zhu } \\
\text { Hanping, } \\
\text { Jia Haiwei }\end{array}$ & 14 & $\begin{array}{l}20 \\
13\end{array}$ \\
\hline 14 & $\begin{array}{l}\text { The rationale and value of } \\
\text { rural community social } \\
\text { organizations participating } \\
\text { in providing community } \\
\text { public services }\end{array}$ & Sun Diliang & 13 & $\begin{array}{l}20 \\
15\end{array}$ \\
\hline 15 & $\begin{array}{l}\text { Research on the } \\
\text { Cooperative Supply of } \\
\text { Public Service from the } \\
\text { Perspective of the Whole } \\
\text { Government }\end{array}$ & $\begin{array}{l}\text { Guo } \\
\text { Jianqiang, } \\
\text { Du Jinsui }\end{array}$ & 12 & $\begin{array}{l}20 \\
13\end{array}$ \\
\hline
\end{tabular}

\section{B. Analysis of Theme Evolution}

The historical span of the study on "coordinated supply of public services" is not long, and the number of papers is small, but the research content and areas of concern are rich. The study finds that scholars are concerned mostly about keywords such as -eoordinated supply", public service", public goods" and trban community"; in time series, relevant research began in 2009, the research results broke out in 2013, and there was an intensive growth of papers involving regional synergy integration", big data" and internet+" in 2017. Related research mainly includes: 
1) Research on the connotation and practice of public service coordinated supply: As a major consensus in today's world, strengthening public service supply is the basic responsibility and main goal of a service-oriented government [9]. The 19th National Congress emphasized the promotion of people's well-being, the promotion of fairness and justice, and the people's sense of well-being and happiness. The academic research on the supply of public services is also increasing. Most of them are based on service content, financial input, and public investment. They pay more attention to the behavior logic and supply content of government public services, regional imbalances and inefficiencies [10] [11] [12] [13] [14] [15] [16] (Jiang Xiaoping, 2013; Gong Feng et al., 2009; Ni Hongri et al., 2012; He Yanling et al., 2014; Li Yongyou, 2011; Lin Wanlong, 2007; Liu Pozhi, 2007). With the transfer of governments' pursuit gradually shifting from economic growth to social life [17] (Gao Lin, 2012), the number and proportion of public service fiscal expenditures in China are gradually increasing, and the level of supply and equalization is improved [18] ( $\mathrm{Yu}$ Jianxing, etc. 2012), but public satisfaction is not ideal [19] (Hu Wei et al., 2013). The choice of supply methods and the decision of the supply plan have become the main reasons for the inefficiency of supply.

Academic research sometimes does not conform to the goal of achieving public value and improving the quality of public services [20] (Osborne, 2013), and is easily limited to examining the internal organizational structure, power mechanisms, organizational management, etc. [21] (Boyne, 2003). The expression of multi-stakeholders is more in line with the optimal way of collective action logic and the requirements of citizens to participate in public governance [22] (Ostrom, 2000). In order to enhance the performance of public service provision, more and more scholars [23] (Fan Bainai, 2016) believe that the idea of simply emphasizing government supply should be jumped out. The public service supply should not exclude the direct provision of services by bureaucracies (Owen Hughes, 1994), and should also accept the pluralistic governance structures of countries, market dualities, and even diversity structure with countries, markets, and civil society [24] (Yu Keping, 2008). This coincides with synergetics": the effects of joint actions of various subsystems around common goals are greater than the effects of individual operations. Eollaboration" is the process in which each subsystem competes and cooperates spontaneously to form an ordered state [25] (Haken, 1997).

Tian Yuqi (2015) believes that "coordinated supply of public services" means that government departments, market organizations and social organizations are guided by people's needs, through full communication and coordination, to achieve complementary advantages and information and resource sharing, and under the guidance of certain rules, all of them coordinate, cooperate with each other, and jointly provide public service. [26] Coordinated methods generally include: inter-subjects, such as inter-governmental relations, through the unified operation mechanism and the construction of a network organization system to solve the problem of uneven supply of urban and rural public services
[27] (Zhang Xianming, 2015); coordination between different subjects gives the social, public welfare, and service functions to enterprises and social organizations in the form of contractualization, [28] (Zheng Qiao, 2008). The Public Service coordinated Supply" focuses on the synergy between multiple entities. The biggest difference from the traditional government single supply method is the multi-dimensional interaction and the common pursuit of the maximization of public interest.

In summary, the coordinated supply of public services is the product of social practice and theoretical application, but what are the synergistic motivations of each subject? Can we benefit from synergy? Scientific explanations and normative proofs are also needed.

2) Multi-model research on coordinated supply of public services: At present, China has initially formed the institutional basis for the coordinated supply of public services and government purchasing services, PPP, market and social diversified supply models [29] (Xie Lai, 2017; Zhang Xianming, 2015; Zheng Qiao, 2008). The integrated supply of public service areas embedded in the intergovernmental cooperation process effectively broke the dual structure and differences between regions, eliminated the discrimination of household registration, and achieved the equalization of public service supply [30] (Zhu Hongqi, 2010). With the deepening of the -ne Belt, One Road" development strategy, regional integration and cooperation games can effectively narrow the regional differences in public service supply [31] (Wang Baozhong, 2013). Under the condition of incomplete information and bounded rationality, there is an optimal stability strategy for multiagent coordinated supply [32] (Xu Ying et al., 2017).

Compared with the traditional government supply model, the public-private partnership of public service coordinated supply can improve the supply efficiency [33] (Emerson, 2012), but it will also lead to the loss of public interest due to excessive dependence on the market [34] (Savas E, 2000), bringing certain potential risk. In fact, the government purchase facing the double defects from the demand side and the supply side, it is difficult to become a "smart buyer" [35] (Zhan Guobin, 2013). There are opportunism, supplier monopoly and other social risks need to be guarded [36] (Zhou Jun, 2010), Such as the inequality between the local government and the incompatibility between the game, becoming the biggest obstacle to the coordinated supply of household registration public services [37] (Li Xiaofei, 2016). Coordinating the negative externalities and benefits of the people, the market, and the government is also an urgent problem for the coordinated supply of public service [38] (Zhang Guolei, 2017).

In summary, a few scholars have studied the progress of the public service coordinated supply, but how to make a coordinated plan to prevent social risks requires an in-depth study by the academic community.

3) Research on the influencing factors of coordinated supply of public services: The key element of public service 
supply is capacity. Scholars have mainly studied from the aspects of connotation, content and influencing factors. The connotation perspective has its own emphasis: Li Songlin [39] (2014) thinks it is the number of public services provided in accordance with public expenditure preferences under the constraints of resources; [40] Wang Weitong (2016) believes that under the internal conditions and possibilities, it is the embodiment of the relationship with which the market and civil society are coordinated. Content composition continues to develop: Fang Qian [41] (2009) believes that government public service capabilities include resilience, self-renewal, openness and high efficiency; Xie Laiwei [42] (2016) believes that it includes information development and utilization capabilities, service varieties and technological innovation capability, value goal and balance ability, responsibility sharing and interest coordination ability, and supply organization ability.

Scholars also found that the supply of public services is affected by many factors, including long-term lack of government service functions and misplacement, offside and resource differences [43] (Sheng Mingke, 2015), financial pressure, imperfect incentive mechanism[44] (Chen Xiaochun, 2017), lack of supply awareness, low marketization, economic development, institutional environment, scale of fiscal expenditure, administrative and institutional efficiency, government behavior patterns, etc. [45] (Xie Zhiju, 2016); what's more, there are static influence factors such as interests, resources, goals, social capital, trust, interaction, institutions, and information technology [46] (Tian Yuxi, 2015) and dynamic influence factors such as business process, communication feedback, and mutual trust level (He Jixin et al, 2015).

In summary, the academic community has conducted a preliminary study on the supply capacity and influencing factors of public services, but it is still necessary to combine the influencing factors with the most important indicators of measurement ability, performance, to conduct a comprehensive and systematic study.

\section{LITERATURE REVIEW AND SPACE FOR FURTHER RESEARCH}

Although the research on the coordinated supply of public services in China is on the rise, the research has achieved relatively fruitful results, and the definition analysis of the connotation, practice, multiple modes and influencing factors of the coordinated supply of public services has been initially carried out.

\section{A. Limitations of Current Literature Research}

There is less research on the main audience of public services, that is, the public services enjoyed by the public and their true satisfaction. The public as the most important beneficiary of public services, the government's effective supply and rational distribution of public services should be based on a full understanding of the needs of citizens and scientific statistics. The public's real demand and satisfaction with public services is the reference for truly effective public service provision. However, there is currently less research on the public's true service level and its satisfaction with public service.

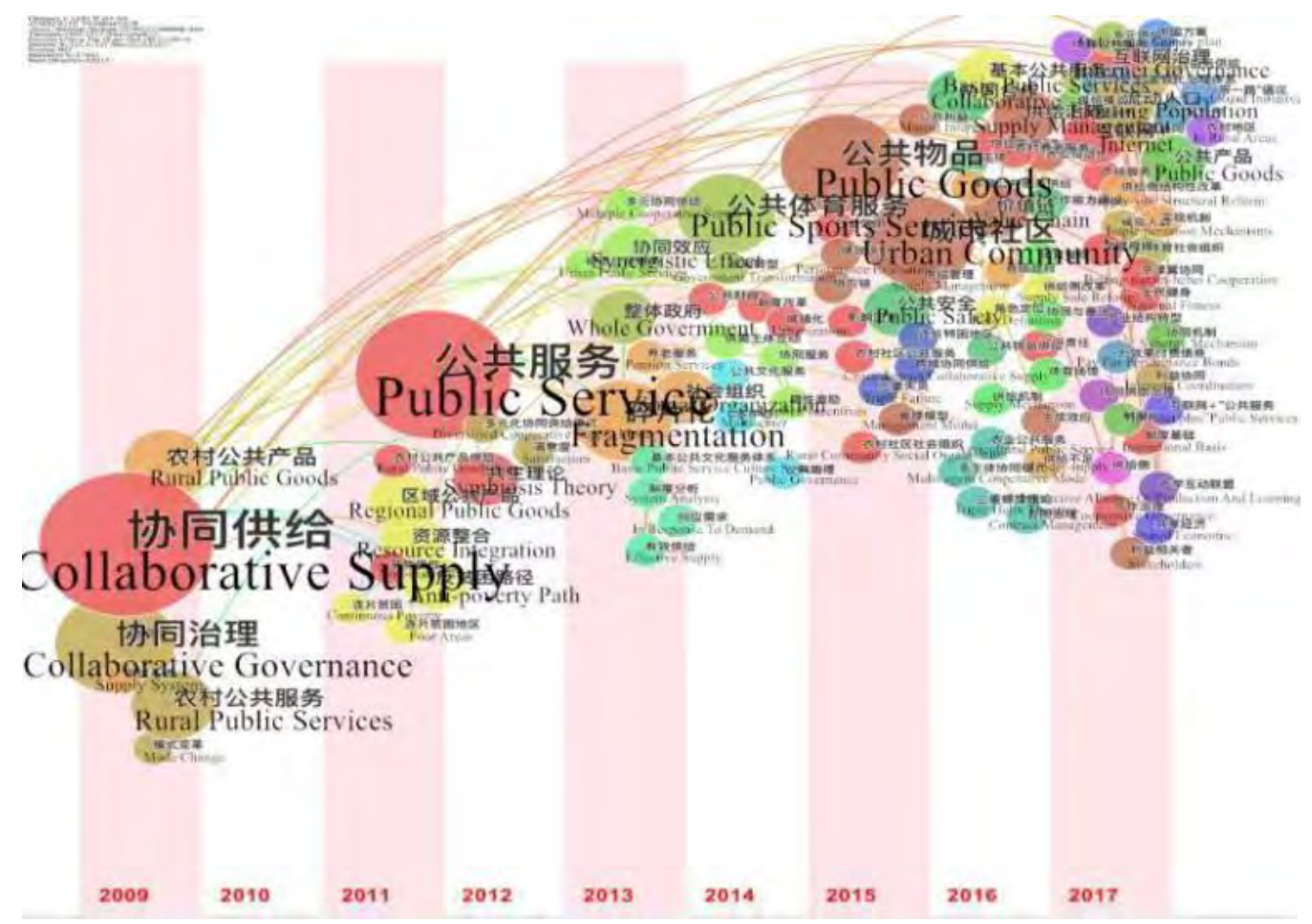

Fig. 1. The evolution of Knowledge Atlas of "public Service cooperative supply" core periodicals. 
The research on the performance of public service coordinated supply is in its infancy, and the theoretical analysis of coordinated supply needs to be further studied.

Research on the coordinated supply of public services has been carried out. What's the effect of coordinated supply of public services, whether supply and demand matches or not and how the public satisfaction is. All these questions are required to respond through the performance evaluation of public service coordinated supply, but the performance research on the coordinated supply of public services is still insufficient. At the same time, research on why coordinated supply of public services requires coordinated supply and the real motive of coordinated supply needs to be deepened.

The research on the coordinated supply of public services in ethnic areas is relatively scarce. The coordinated supply of public services has become a new mode of effective supply of public services. The coordinated supply of public services is a frontier topic and practice hotspot in the field of public management in China. The number of academic achievements on the coordinated supply of public services in ethnic areas is small and not mutually exclusive. The system is in the ascendant to its research. The research on the cooperative supply mechanism of public services in ethnic areas can enrich the theoretical research on the study of public service supply. Systematically analyze the current situation of public service coordinated research in ethnic areas can promote the development of basic public services in frontier ethnic areas, and contribute to the fairness of residents in frontier ethnic areas. The enjoyment of basic public services will help the unity and stability of the frontier ethnic areas and realize the great dream of unity, mutual assistance and common development of all ethnic groups in the country.

\section{B. Further Research Trends}

According to the domestic literature analysis on the coordinated supply of public services, a comprehensive analysis of highly cited literature and subject evolution reveals what the future research can do:

First, explore the future development trend of the research on the coordinated supply mechanism of public services. China's research on the coordinated supply of public services is emerging, but most of them are limited to macroscopic and qualitative discussions on historical inevitability, background, concept, operational mechanism, and practical cases. There is no systematic study on the future supply of public services. With the deepening of the understanding of public service coordinated supply, the practice development and reform and innovation, and the promotion of regional coordinated development strategy and the arrival of the artificial intelligence era, it is urgent to explore the establishment of a scientific theoretical system for the coordinated supply of public services.

Second, explore the quantitative analysis method of coordinated supply of public services. With the deepening of the understanding, practice development and reform, and innovation of the public service coordinated supply in all walks of life in our country, it is urgent to improve the theoretical system of constructing the coordinated supply of public services, explore the use of standardized models and methods, and study the issues of coordinated motivation, how to make decisions, and synergy performance. In practice, it guides the government, enterprises, and the public to actively cooperate, make scientific and rational decisionmaking, and focus on the performance of more secure and more sustainable supply.

Third, study on the coordinated supply mechanism of public services in ethnic areas. For the status quo and problems of the coordinated supply of public services in ethnic areas, it is important to systematically and deeply analyze how to promote the coordinated supply of public services, further promote the implementation of regional coordinated development strategies, narrow the regional development gap, implement national development policies, and guarantee the survival rights of ethnic minorities. The requirements of the right to development enable the effectiveness of social governance to benefit more, better and more equitably benefit all the people, solve the contradiction between the people's growing needs for better life and the development of unbalanced development, and promote the innovation of public services in the frontier minority areas. Development is of significance, and scholars should further promote the research on the coordinated supply mechanism of public services in ethnic areas.

\section{CONCLUSION}

As an important means for ruling parties and the public sectors to integrate social resources, enhance people's wellbeing, and enhance their ability to govern, public service supply has received much attention in recent years. This paper analyzes the trends and hotspots of domestic public service coordinated supply through knowledge map supported by Citespace software, which showed that although the research on the coordinated supply of public services in China is emerging, there are certain limitations and still a lot of research to be done in the future.

\section{ACKNOWLEDGMENT}

This research was supported by the China national natural science foundation - Research on evolution game, decision optimization and performance evaluation of cooperative supply of public services" and the Enhancing Comprehensive Strength Foundation of Inner Mongolia University.

\section{REFERENCES}

[1] Denhardt R B, Denhardt J V. The New Public Service: Putting Democracy First[J]. National Civic Review, 2010, 90(4):391-400.

[2] Zhang Kangzhi, Jiang Ningning. Research on public management in social governance reform — the National People's Congress photocopy data "public administration" of the key to 2016 and 2017 research forecast [J]. China administration, 2017 (02): 47-55.

[3] Jiang Xiaoping, Chen Chaobing. Common trend and regional difference of basic public service system in china - based on the comparison of the Twelfth Five-year Plan of national and local basic public service[J]. Journal of Shanghai Institute of Administrative sciences, 2013,14 (06): 4-16. 
[4] Yu keping. Chinese governance changes in the last thirty years (19782008) [J]. Jilin University of Social sciences, 2008 (3): 5-17.

[5] He Yanling, Wang Guanglong, Chen Shiguo. Political analysis of urban government expenditure in China $[\mathrm{J}]$. Chinese social sciences, 2014 (07): 87-106+206

[6] Li Yongyu. Public service-oriented government construction and fiscal expenditure structure efficiency $[\mathrm{J}]$. comparison of economic and social systems, 2011 (01): 67-78.

[7] $\mathrm{Hu}$ wei, $\mathrm{Wu}$ wei. Blue Book on public satisfaction of urban public service in China [M]. shanghai: Shanghai People's Publishing House, 2013.

[8] Tian Yuqi. Cooperated supply of public services: basic connotation, social utility and influencing factors $[\mathrm{J}]$. Yunnan Social sciences, 2015 (03): 7-13

[9] Fan Bonai, Jinjie. The influence mechanism of public service supply on perceived performance of public service - the mediating effect of government image and the moderating effects of public participation [J]. management world, 2016 (10): 50-61+187-188

[10] Jang Xiaoping, Chen Chaobing. Common trend and regional difference of basic public service system in china - based on the comparison of the Twelfth Five-year Plan of national and local basic public service $[\mathrm{J}]$. Journal of Shanghai Institute of Administrative sciences, 2013,14 (06): 4-16.

[11] Gongfeng, Lu Hongyu. Public expenditure structure, preference matching and fiscal decentralization [J]. management world, 2009 (01): 10-21.

[12] Ni Hongri, Zhang Liang. Research on the Equalization of basic public services and the reform of financial management system [J]. Management world, 2012 (09): 7-18+60.

[13] He Yanling, Wang Guanglong, Chen Shiguo. Political analysis of urban government expenditure in China [J]. Chinese social sciences, 2014 (07): 87-106+206

[14] Li Yongyu. Public service-oriented government construction and fiscal expenditure structure efficiency $[\mathrm{J}]$. Comparison of economic and social systems, 2011 (01): 67-78.

[15] Lin Wanlong. Structural imbalance of supply and demand of rural public services in China: manifestations and causes [J]. managing the world, 2007

[16] Liu Qiongzhi. Public expenditure: Is the Government's public service implemented in the hands of the poor?[J]. Management world, 2007 (04): 60-67.

[17] Gaolin. Decentralization and people's livelihood: an empirical study on the impact of fiscal autonomy on public service satisfaction [J]. economic research, 2012,47 (07): 86-98.

[18] Yu jianxing, Gao Xiang. Behavioral logic and institutional basis of local development government [J]. Chinese social science. 2012 (05).

[19] $\mathrm{Hu}$ wei, Wu wei. Blue Book on public satisfaction of urban public service in China [M]. shanghai: Shanghai People's Publishing House. 2013.

[20] Osborne S P, Radnor Z, Nasi G. A New Theory for Public Service Management?: Toward a (Public) Service-Dominant Approach[J]. American Review of Public Administration, 2013, 43(2):135-158.

[21] Boyne G A. Sources of Public Service Improvement: A Critical Review and Research Agenda[J]. Journal of Public Administration Research and Theory, 2003,13(3):367-394.

[22] Ostrom. The governance of public affairs [M]. Beijing: Joint publishing, 2000.

[23] Fan Bonai, Jinjie. The influence mechanism of public service supply on perceived performance of public service — the mediating effect of government image and the moderating effects of public participation [J]. management world, 2016 (10): 50-61+187-188.

[24] Yu keping. Chinese governance changes in the last thirty years (19782008) [J]. Jilin University of Social sciences, 2008 (3): 5-17.

[25] H. Haken. Synergetic:an introduction[m], Berlin:spring-verlog, 1997.

[26] Tian Yuqi. Cooperated supply of public services: basic connotation, social utility and influencing factors $[\mathrm{J}]$. Yunnan Social sciences, 2015 (03): 7-13.
[27] Zhang Xianming, Tian Yuqi. Integration fragmentation: The path of collaborative supply of public services [J]. social Science front, 2015 (09): 176-181.

[28] Zheng qiao, Xiaowentao. Cooperated governance: the logic of governance of service-oriented government $[\mathrm{J}]$. China administration, 2008 (07): 48-53.

[29] Xie Laiwei, Zhong Yumin. Theoretical basis and institutional basis for the cooperative supply of public services $[\mathrm{J}]$. Journal of Shanghai Institute of Administrative sciences, 2017,18 (02): 49-59.

[30] Zhu Hongqi. Reform of education system and integration of urban and rural education - breaking the system bottleneck of dual structure of urban and rural education $[\mathrm{J}]$. educational research 2010,31 (11): 3-11.

[31] Wang Baozhong, He Liancheng, Li Zhongmin. Integrated strategic path and implementation countermeasures of "new Silk Road economic belt" [J].Economic aspect, 2013 (11): 60-65.

[32] Xu Ying, Ge Xinquan, Wang Wei. The analysis of the evolutionary game behavior of the Three-party main body of the reverse logistics of urban refuse classification - the exploration of the market operation mode based on garbage classification and recovery [J]. Economic Research reference, 2017 (40): 79-88.

[33] Emerson K, Nabatchi T, Balogh S. An Integrative Framework for Collaborative Governance[J]. Journal of Public Administration Research \& Theory, 2012, 22(1)

[34] Savas E. Privatization and Public-Private Partnerships for Local Services[J]. Chatham House, 2000, 87(1):21-23.

[35] Zhan Guobin. Demand-side defects, supply-side defects and savvy buyers - the dilemma of government purchasing public services and its solution [J]. Comparison of Economic and social systems, 2013 (05): 142-150.

[36] Zhou Jun. The risk of government purchasing public services and its prevention [J]. China administration, 2010 (06): 13-18.

[37] Li Xiaofei. The inter-provincial game and benefit integration in the reform of the household registration system $[\mathrm{J}]$. Administrative forum 2016,23 (03): 43-48.

[38] Zhang Guolei. Inter-Government game, Grassroots mobilization and "anti-neighbour" effect — based on the domestic "high-speed war" analysis [J]. Beijing Social science, 2017 (07): 58-68.

[39] Li Songlin. Enlightenment of new public service theory on construction of service-oriented government in China [J]. Journal of theory, 2014 (02): 88-90.

[40] Wang Weitong, Tang Yumeng, Wei Shen'guang, Performance evaluation of basic public services based on the perspective of People's Livelihood satisfaction - analysis of data from Chinese family dynamic tracking [J]. local finance research, 2016 (03): 51-56.

[41] Fang Qian, Zhang Xu. Study on the explanatory structure model of public service capacity in ethnic areas [J]. Reform and strategy, 2009,25 (04): 112-114+182.

[42] Xie Laiwei, Zhong Yumin. Theoretical basis and institutional basis for the cooperative supply of public services [J]. Journal of Shanghai Institute of Administrative sciences, 2017,18 (02): 49-59.

[43] Sheng Mingke, Zhu Yumei. Suggestions on innovation achievement evaluation system under the guidance of ecological civilization construction [J]. China administration, 2015 (07): 156.

[44] Chen Xiaochun, Peng Yanhui, Chen Wenjie. Study on the regulation of the legalization of non-governmental organizations outside China [J]. China administration, 2017 (07): 87-91

[45] Xie Zhiju. The types, harms and corrections of poor justice in Socia governance [J]. Journal of CPC Fujian Provincial party school, 2016 (05): 35-42.

[46] He Jixin, Yang Peng, Gao Yajun. Multi-agent Cooperative supply of public goods in urban community: status evaluation and influencing factors [J]. Journal of Jishou University (social Sciences edition), $2015,36(04): 77-87$ 